\title{
A study on the relationship between internal and external audits on financial reporting quality
}

\author{
Mohammad Jamal Azzama*, Hussein Mohammed Alrabba ${ }^{\text {a }}$, Alaa Mohammad AlQudah ${ }^{\text {a }}$ and \\ Hasan Mohammad Anwar Mansur ${ }^{b}$
}

${ }^{a}$ Department of Accounting, Yarmouk University, Irbid, Jordan

${ }^{b}$ Department of Accounting, Szent Istvan University, Gödöllö, Hungary

C H R O N I C L E A B S T R A C T

\begin{tabular}{l} 
Article history: \\
Received: July 102019 \\
Received in revised format: Sep- \\
tember 192019 \\
Accepted: October 2, 2019 \\
Available online: \\
October 2, 2019 \\
\hline Keywords: \\
Internal Auditors \\
External Auditors \\
Financial Reporting Quality
\end{tabular}

\section{Introduction}

Internal audit is a function in a company that operates independently from other departments. Internal auditors report directly to audit committees. In preparation of reports and carrying out their duties, internal auditors consider the effect of their decisions made on the businesses (Muqattash, 2011). External audit is an external body appointed by the shareholders to investigate the company's financial accounts. The main responsibility of the external audit is to prepare the annual statutory audit of the financial accounts, and opinionate on whether the accounts are a true and fair reflection of the company's financial position. At some point in a company's operating fiscal year, the stakeholders will require to be supplied with details, certified and up to date reports on the proceeding of the company. Power has been vested upon auditors to compile such reports (Beattie et al., 2002). Reports on status quo of the company provided to the shareholders, and by extension the governments assist in decision making among other roles. The stakeholders would like to know whether or not the company is making the right steps towards its objectives. While the government would like to make a more reliable estimate of several matters, for instance, taxing. The most common analytical technique used by external auditors to conduct their work is called alpha. The important application of alpha is evident in the work of inspection and audit at different stages to produce results, and an analysis of the relationships and ratios, and important trends between the terms of the financial statements. It is also applied in finding relationships between financial and non-financial statements derived from a similar period or compares such information for different periods or companies. To assure that the stakeholders are provided a report they can trust, both internal and external auditors work in cohesion to come up with a concrete report. In this regard, this study is here to identify the effect on the reporting between internal and external auditors. It is important to maintain a good relationship between external and internal auditors, since internal auditors are valuable sources of information, and indeed, they are more familiar with the company and its environment (Dobroţeanu et al., 2002).

* Corresponding author. Tel.: +962799313686

E-mail address: moh.azzam@yu.edu.jo (M. J. Azzam)

(C) 2020 by the authors; licensee Growing Science, Canada doi: $10.5267 /$ j.msl.2019.10.001 and its environment. This study aimed to identify the relationship between internal and external audits affecting the quality of firms' reports. To achieve the objectives of the study, a 30-item questionnaire was developed and statistics and multiple regression were used to test the hypotheses of the study. The results show that Jordanian auditors perceived favorably the cooperation between internal and external auditors to enhance the quality of reporting quality. Moreover, the quality of financial reporting has been affected positively resulting in the posation between the two auditing teams was noticeable through the nature and scope dimension that, in turn, increased the quality of financial reporting. Based on these results, external auditors are highly recommended the level of cooperation between internal and external auditors in a way that increased the level of financial 


\section{Significance of the Study}

Most companies are consistently facing challenges arising from misappropriation of funds, and fraud, often destabilizing their operations. This information is either disclosed or hidden from the shareholders in the financial reports. In such a situation, the management will have to work to maintain a business position in the economic map. Improper reporting gives the wrong impression of a business, putting it at risk of both legal and in-house challenges. This result to greater responsibilities faced by the management (Brewster et al., 2016). Market environments are a fast-growing complexity, added to the fact that it quickly transforms and changes, which entails businesses to concentrate on factors which are most critical to the existence of the organizations. These factors include carrying out cohesive internal and external audits to ensure the reports produced are reliable and can be accounted for. From the foregoing, it is essential that shareholders of businesses must be assured of a true and fair reflection of the business through efficient reporting. Studying the crucial matters relevant to the company to serve the purpose as well as its objectives will determine and identify its success. In this light, this study aims on analysing the need for cooperation between internal and external auditors during the report preparation process. Additionally, it will serve as a guideline for other companies that are desirous of a true and fair reflection. This study will also be significant to companies in Jordan. The survey of the research study will help determine how the relationship between internal and external audits affect the reporting process. This will also help initiate and implement management, as it may pinpoint ways ensuring an increased relationship, which could mostly be relevant to the achievement of shareholder satisfaction.

\section{Literature Review and Hypotheses Development}

Internal control is defined as a process within an organization designed to provide reasonable assurance regarding primary corporate objectives such as the reliability and integrity of information, compliance with policies, plans, procedures, laws and regulations, and the safeguarding of assets (Institute of Internal Auditors, 2018). External audit is the audit carried out from independent external sources. Reporting is the supply or provision of information regarding a company's current and past financial status. The relationship between the internal and external audits escalate shareholder satisfaction a great deal. This relationship shows a positive correlation between audit efficiency and quality, reputation of auditors, charges for auditing, size of the firm carrying out the audit and the auditor's proficiency. To enhance transparency, the Corporate Governance Code (CGC) obliges listed firms on the Amman Stock Exchange (ASE) to create an audit committee. The audit committee has several responsibilities such as support supervision and accountability in financing, ensure the management complies with internal control and accounting policies, review conclusions of the internal audit department to ensure they adhere to the committee's recommendations and to recommend an external auditor for appointment (CGC 2008). Going forth, the internal auditors seem to have a big control of the internal accounting and finance matters of the company. The task of suggesting an external auditor could help maintain proper reports, if the external auditor recommended is competent enough and understands the company's operations. Establishing a clear framework for the relationship between external and internal audit lies at the heart of the International Standard on Auditing (ISA) 610. The aim is to produce more transparency in reviewing and auditing companies' financial reports. It also enhances the attractiveness of any context's business environment for investments. ISA 610 defined the aspects of cooperation between external and internal audit. Such cooperation most likely enables external auditors to depend more on the work of a company's internal audit, which in turn facilitates the audit process. Most of previous studies, however, have investigated the direct association between either internal audit (Badolato, et al., 2014; Hameed et al., 2017; Ittonen et al., 2017) or external audit (Abdallah, 2018; Dimitras et al., 2015; Jordan et al., 2010) and financial reporting quality. Thus, very limited research has been done regarding the relationship between the two types of audit and the quality of companies' reports. Earlier studies such as Mautz (1984) reveals that the relationship between internal and external auditors is positive and such relation is expected to confer benefits to firms. Maletta et al. (1993) and Krishnamoorthy (1997) find that external auditors use internal auditors' work as an assistance, especially when the objectivity of the internal audit is very high. Al-Twaijry et al. (2004) show that internal auditors believe that cooperation with external auditors is very limited, whereas external auditors consider it as a good tool to enhance audit quality. In the same vein, Haron et al. (2004) find that the scope in function and competence of the internal audit's work are the vital factors where external auditors rely on to reduce audit cost as well as produce high quality auditing. Gras-Gil et al. (2012) and Garcia-Perez de Lema (2012) find that the likelihood of having high quality financial reporting is more accentuated in companies where the collaboration between external and internal auditors is very high. Davidson et al. (2013) reveal that external auditors focus more on internal audit only when periodic auditing is used. More recently, Quick et al. (2018) find that prior experience of an external auditor with the quality of a company's internal audit plays a pivotal role in enhancing and accelerating the audit process. In line with previous studies and following ISA 610, the following hypotheses regarding the effect of the relationship between internal and external audits on financial reporting quality are formulated:

$\mathrm{H}_{1}$ : The objectivity of the internal audit's work increases the cooperation between internal and external audit, which in turn enhances the quality of financial reporting.

$\mathrm{H}_{2}$ : The technical competence of the internal audit's work increases the cooperation between internal and external audit, which in turn enhances the quality of financial reporting.

$\mathrm{H}_{3}$ : The professional care of the internal audit's work increases the cooperation between internal and external audit, which in turn enhances the quality of financial reporting.

$\mathrm{H}_{4}$ : The nature and scope of the internal audit's work increases the cooperation between internal and external audit, which in turn enhances the quality of financial reporting. 


\section{Methodology of the Study}

Questionnaire was developed and sent to Jordanian external auditors to examine their perception on the effect of the relationship between internal and external audits on financial reporting. Sekaran et al. (2016) stress that the questionnaire survey is the most common method of collecting data because it permits the researcher to use visual aids to clarify points; and it is most useful in data collection when large numbers of people in different places are to be reached.

\subsection{Instrument Validity and Reliability}

Before distributing the questionnaire to the respondents, five lecturers at three Jordanian universities were asked to give feedback on the items asked to ensure the suitability and clarity of the items. After considering all the recommendations given, a pilot test was run on a sample of 30 external auditors. The reliability of the instrument of this study was tested using Cronbach's alpha. According to Hair Jr et al. (2015), the instrument is deemed to be acceptable when the alpha value is above 60 percent. Table 1 shows that the reliability coefficients of the questionnaire's items are more than 70 percent, which is considered as highly reliable.

\section{Table 1}

Reliability Coefficients of Measurement of Variables

\begin{tabular}{clc}
\hline No. of Items & Variables & Cronbach's Alpha \\
\hline 6 & Financial Reporting Quality & 0.887 \\
5 & Objectivity & 0.865 \\
6 & Technical Competence & 0.823 \\
6 & Professional Care & 0.764 \\
7 & Nature and Scope & 0.844 \\
\hline
\end{tabular}

\subsection{Sample Characteristics}

Sekaran et al. (2016) define sampling process as selecting a sufficient number of elements from population. In this study, the population is Jordanian external auditors. The Jordan Association of Certified Public Accountants (JACPA) 2018 records indicate that there are 521 certified auditors. The questionnaire was sent to 312 external auditors, only 276 questionnaires were returned with full data yielding 88.5 percent responses rate. Table 2 highlights the demographic profile of the respondents.
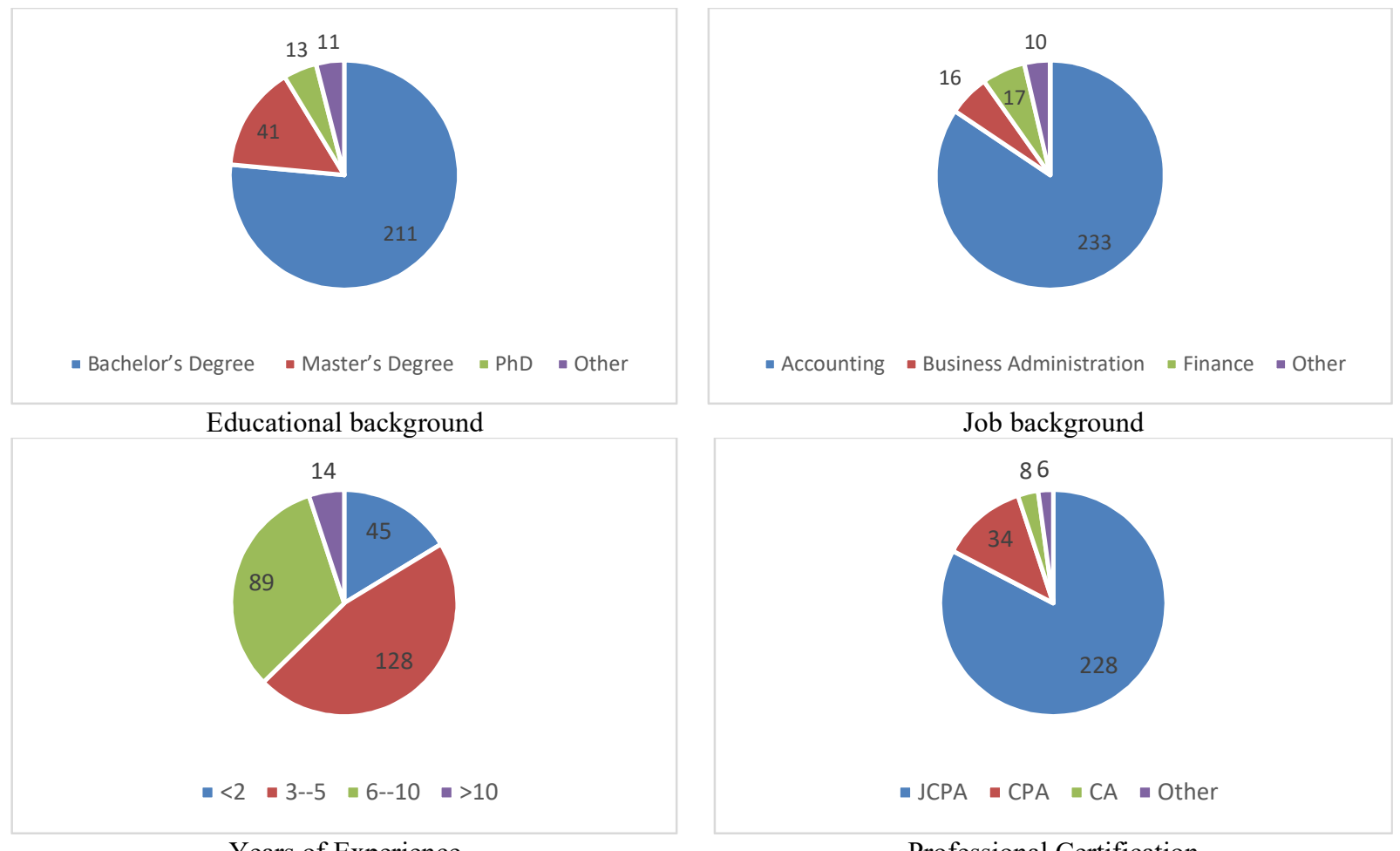

Fig. 1. Personal characteristics of the participants

Fig. 1 shows that 76.4 percent of the auditors held a bachelor's degree. Those with a master's degree were only 14.9 percent, and the remaining either had $\mathrm{PhD}$ (4.7 percent) or other degrees (4 percent). Regarding the specialization of the Jordanian auditors, most of the respondents majored in accounting ( 84.4 percent); 6.2 percent in finance; 5.8 percent majored in business 
administration; and only 3.6 percent majored in other fields. In relation to auditors' experience, The figure also shows that 46.4 percent of the auditors have three to five years of work experience; 32.2 percent had experience in auditing between six and ten years; and the others either have less than two years of experience (16.3percent), or more than 10 years of experience (5.1percent). Most Jordanian auditors have JCPA (82.6 percent); 12.3 percent have CPA; 2.9 percent have CA, and only 2.2 percent have other certifications.

\subsection{Factor Analysis}

Factor analysis is a technique that is used to reduce the variables to smaller number factors. Before using the factor analysis, we have checked the assumptions of normality, homoscedasticity, and linearity (Hair et al., 2015). In doing so, Kaiser Meyer Olkin (KMO) was used to measure sampling adequacy, also, Bartlett's test of sphericity is used to test the inter-correlation among the factors. Table 2 illustrates the KMO guide to interpret values of factor analysis (Kaiser, 1974)

Table 2

KMO Test Guide

\begin{tabular}{llll}
\hline KMO & Opportunity for factor analysis & KMO & Opportunity for factor analysis \\
\hline 0.90 to 1.00 & Marvelous & 0.60 to 0.69 & Mediocre \\
0.80 to 0.89 & Meritorious & 0.50 to 0.59 & Miserable \\
0.70 to 0.79 & Middling & Below 0.50 & Should be excluded \\
\hline
\end{tabular}

\subsection{Reliability of Measurement}

Reliability was tested again after factor analysis to ensure the reliability of the instrument. According to Nunnally (1978), to assess the reliability of the instrument, Cronbach's alpha is considered an adequate test of the reliability of the survey instrument. Table 3 shows that the Cronbach's alphas range from 70.8 percent to 86.4 percent, which exceeds the minimum value of 70 percent to be acceptable (Sekaran et al., 2016). This means that the instruments used to measure the variable were acceptable and the data were later used for further analyses.

Table 3

Reliability Coefficients

\begin{tabular}{lccc}
\hline Variables & Cronbach's Alpha & Variables & Cronbach's Alpha \\
\hline Financial Reporting Quality & 0.792 & Professional Care & 0.853 \\
Objectivity & 0.864 & Nature and Scope \\
Technical Competence & 0.845 & \\
\hline
\end{tabular}

\subsection{Criterion Validity}

Hair et al. (2015) claimed that there is a high collinearity between variables when the correlation is above 90 percent. This study depends on the tolerance (TOL), and the variance inflation factor (VIF) to test collinearity. The values of TOL should be above 10 percent and the VIF should be less than 10. Table 4 below indicates no multi-collinearity among the variables since the values of variance inflation factor VIF ranged from 1.430 to 1.987 and the values of tolerance TOL ranged from 50.3 percent to 69.9 percent.

\section{Table 4}

Multicollinearity Diagnoses of Qualitative Characteristics

\begin{tabular}{llllc}
\hline Variables & Tolerance & VIF & Variables & Tolerance \\
\hline Objectivity & 0.647 & 1.546 & Nature and Scope & 0.597 \\
Technical Competence & 0.503 & 1.987 & Financial Reporting & 0.531 \\
Professional Care & 0.699 & 1.430 & & 1.882 \\
\hline
\end{tabular}

\subsection{Linearity, Normality, and Homoscedasticity}

We have tested linearity, normality, and homoscedasticity before we tested the hypotheses. The scatter plots expressed normal line for the independent and dependent variables.

Table 5

Result of Skewness and Kurtosis Tests

\begin{tabular}{|c|c|c|c|c|}
\hline \multirow[t]{2}{*}{ Variable } & \multicolumn{2}{|c|}{ Skewness } & \multicolumn{2}{|c|}{ Kurtosis } \\
\hline & Statistic & Std. Error & Statistic & Std. Error \\
\hline Objectivity & -.543 & .211 & -.215 & .312 \\
\hline Technical Competence & -.432 & .211 & .453 & .312 \\
\hline Professional Care & -.699 & .211 & .402 & .312 \\
\hline Nature and Scope & -.782 & .211 & .226 & .312 \\
\hline Financial Reporting Quality & -.329 & .211 & -.198 & .312 \\
\hline
\end{tabular}


Additionally, we have tested normality of the data by exploring Skewness and Kurtosis ratio. The results show that the Skewness and the Kurtosis ratios are between \pm 1.96 and \pm 2.58 , respectively which indicate the data is normally distributed (Pallant, 2013).

\subsection{Descriptive Statistics}

After reviewing the respondents' profile, this section presents the descriptive results of the variables under study, where appropriate. Table 6 shows that, in general, Jordanian auditors had moderate and favorable perception towards the relationship between cooperation between internal and external auditors in terms of enhancing financial reporting.

\section{Table 6}

Means and Standard Deviations of the Study's Variables

\begin{tabular}{lccc}
\hline Variables & Total number of items & Mean $^{\text {a }}$ & Standard deviation \\
\hline Objectivity & 5 & 3.851 & 3.982 \\
Technical Competence & 6 & 3.799 & .65443 \\
Professional Care & 6 & 3.902 & .62131 \\
Nature and Scope & 7 & 3.829 & .60212 \\
Financial Reporting Quality & 6 & .682345 & \\
\hline
\end{tabular}

Note: ${ }^{a} 1=$ strongly disagree, $2=$ disagree, $3=$ neutral, $4=$ agree, $5=$ strongly agree

\subsection{Hypotheses Testing}

This section presents the findings of the relationship between the dependent variable (financial reporting quality) and the independent variables (objectivity of the internal audit's work, the technical competence of the internal audit's work, the professional care of the internal audit's work, and the nature and scope of the internal audit's work). In doing so, this study used multiple regression to test the hypotheses of the current study. The result of regression shows that $R^{2}$ value is 50.1 percent and $\mathrm{F}$ value is 13.423 . Table 7 exhibits these results.

\section{Table 7}

\section{Regression Results}

\begin{tabular}{|c|c|c|c|c|c|}
\hline & \multicolumn{2}{|c|}{ Unstandardized Coefficients } & \multicolumn{2}{|l|}{ Standardized } & \multirow[b]{2}{*}{ Sig. } \\
\hline & $\mathrm{B}$ & Std. Error & $\mathrm{B}$ & t-value & \\
\hline (Constant) & 2.223 & .031 & & 4.381 & .002 \\
\hline Objectivity & .622 & .110 & .583 & 2.982 & .005 \\
\hline Technical Competence & .433 & .013 & .402 & 3.371 & .000 \\
\hline Professional Care & .329 & .102 & .299 & 4.612 & .004 \\
\hline Nature and Scope & .519 & .010 & .495 & 5.376 & .000 \\
\hline
\end{tabular}

$\mathrm{F}=13.423 \mathrm{R}^{2}=.501 \mathrm{Sig} .=0.05$ Dependent Variable: financial reporting quality

H1: The objectivity of the internal audit's work increases the cooperation between internal and external audit, which in turn enhances the quality of financial reporting.

The result shows that $B$ value is 0.622 (Sig. $=0.005$ ). This means that objectivity of the internal audit's work is significantly and positively increase the cooperation between internal and external audit which in turn enhances financial reporting quality, in which for one unit increase in the independent variable the dependent variable will increase by $0.583(t=2.982, \mathrm{p}=.005)$. Based on this result, the first hypothesis is supported.

H2: The technical competence of the internal audit's work increases the cooperation between internal and external audit, which in turn enhances the quality of financial reporting.

Table 7 exhibits the results of a regression between technical competence and financial reporting quality and shows that the $B$ value is 0.433 (Sig. $=0.000)$. This means that technical competence has increased the cooperation between internal and external audit, which in turn enhances the quality of financial reporting. The table also shows that for each unit increase in the technical competence there is an expected increase in the dependent variable by $.402(t=3.371, \mathrm{p}=0.001)$. Hence, the second hypothesis is supported.

H3: The professional care of the internal audit's work increases the cooperation between internal and external audit, which in turn enhances the quality of financial reporting.

The results show that the $B$ value is 0.329 ( $\mathrm{Sig} .<0.004$ ), which means that professional care has increased the cooperation between internal and external audit, which in turn enhances the quality of financial reporting. Table 7 also shows that for each unit increase in professional care there is an expected increase in financial reporting quality by $.299(t=4.612$, $\mathrm{p}=$ 0.04), Hence, the third hypothesis is also supported.

$\mathbf{H}_{4}$ : The nature and scope of the internal audit's work increases the cooperation between internal and external audit, which in turn enhances the quality of financial reporting.

Table 7 also shows that the $B$ value is 0.519 (Sig. $=0.000$ ), which means that the nature and scope has increased the cooperation between internal and external audit and, in turn, enhances the quality of financial reporting. The result has shown that for each unit increase in nature and scope there is an expected increase in financial reporting quality by $.495(t=5.376, \mathrm{p}=$ 
$0.00)$, Hence, the fourth hypothesis is also supported.

\section{Conclusion}

This study has shed light on the relationship between internal and external audit as well as the quality of reporting using a questionnaire survey among the external auditors in Jordan. Indeed, the cooperation between internal and external auditors and its effects on financial reporting quality has been evaluated through objectivity, technical competence, professional care and nature and scope. Interestingly, the extracted results have shown that the participants perceived favourably the cooperation between internal and external auditors to enhance financial reporting quality. For example, the results have documented positive effect of objectivity in enhancing the level of cooperation between internal and external auditors which increased the level of financial reporting quality. Furthermore, the quality of financial reporting has been affected positively because of the positive effect of the technical competence of the internal audit's work. In terms of professional care, the results indicate that, for each unit increase in professional care there was an expected increase in financial reporting quality. Finally, the cooperation between the two auditing teams was noticeable through the nature and scope dimension that in turn increased the quality of financial reporting. In a nutshell, the results have exhibited the fact that, there was a real cooperation between internal and external auditing teams and the quality of financial reporting has increased. These results imply that both teams were flexible and professional to prepare accurate and reliable financial reports to reflect a good image of firm's financial position. Additionally, the findings have shown that, both teams override the theoretical concepts to be more practical to igniting a real cooperation between them to enhance the quality of financial reporting. Therefore, a firm's principals and other interested groups can relay more in the firm's reports because of their trust in the teams' works.

\section{References}

Abdallah, S. (2018). External auditor type, discretionary accruals and investors' reactions. Journal of Accounting in Emerging Economies, $8(3), 352-368$.

Al-Twaijry, A. A., Brierley, J. A., \& Gwilliam, D. R. (2004). An examination of the relationship between internal and external audit in the Saudi Arabian corporate sector. Managerial Auditing Journal, 19(7), 929-944.

Badolato, P. G., Donelson, D. C., \& Ege, M. (2014). Audit committee financial expertise and earnings management: The role of status. Journal of accounting and economics, 58(2-3), 208-230.

Beattie, V., \& Fearnley, S. (2002). Auditor independence and non-audit services: A literature review. Institute of Chartered Accountants in England and Wales, London.

Brewster, C., Chung, C., \& Sparrow, P. (2016). Globalizing human resource management: Routledge.

Davidson, B. I., Desai, N. K., \& Gerard, G. J. (2013). The effect of continuous auditing on the relationship between internal audit sourcing and the external auditor's reliance on the internal audit function. Journal of Information Systems, 27(1), 41-59.

Dimitras, A. I., Kyriakou, M. I., \& Iatridis, G. (2015). Financial crisis, GDP variation and earnings management in Europe. Research in International Business and Finance, 34, 338-354.

Dobroțeanu, L., \& DOBROȚEANU, C. L. (2002). Audit: concepte şi practici: abordare naţională şi internaţională: Editura Economică.

Gras-Gil, E., Marin-Hernandez, S., \& Garcia-Perez de Lema, D. (2012). Internal audit and financial reporting in the Spanish banking industry. Managerial Auditing Journal, 27(8), 728-753.

Hair Jr, J. F., Wolfinbarger, M., Money, A. H., Samouel, P., \& Page, M. J. (2015). Essentials of business research methods: Routledge.

Hameed, A., Bakar, A., Mughal, N., \& Imran, M. (2017). The Internal Audit and Financial Reporting Quality. Paradigms, 11(2), $223-228$.

Haron, H., Chambers, A., Ramsi, R., \& Ismail, I. (2004). The reliance of external auditors on internal auditors. Managerial Auditing Journal, 19(9), 1148-1159.

Institute of internal auditors (2018) the defietion of interal audit. available on https://na.theiia.org/Pages/IIAHome.aspx

Ittonen, K., Tronnes, P., \& Vähämaa, S. (2017). Do former auditors on the audit committee constrain earnings management? Evidence from the banking industry.

Jordan, C. E., Clark, S. J., \& Hames, C. C. (2010). The Impact Of Audit Quality On Earnings Management To Achieve User Reference Points In EPS. Journal of Applied Business Research, 26(1), 19.

Kaiser, H. F. (1974). An index of factorial simplicity. Psychometrika, 39(1), 31-36.

Krishnamoorthy, G. (1997). External auditor's evaluation of internal audit work: A cascaded inference approach.

Maletta, M. J., \& Kida, T. (1993). The effect of risk factors on auditors' configural information processing. Accounting Review, 681-691.

Mautz, R. (1984). Internal and external auditors: how do they relate. Corporate Accounting, 3(4), 56-58.

Muqattash, R. (2011). The effect of the factors in the internal audit department on the internal auditors objectivity in the banks operating in the United Arab Emirates:(A field study). Journal of International Management Studies, 6(3), 92-100.

Nunnally, J. (1978). Psychometric methods: New York: McGraw-Hill.

Pallant, J. (2013). SPSS survival manual: McGraw-Hill Education (UK).

Quick, R., \& Henrizi, P. (2018). Experimental evidence on external auditor reliance on the internal audit. Review of Managerial Science, 134.

Sekaran, U., \& Bougie, R. (2016). Research methods for business: A skill building approach: John Wiley \& Sons.

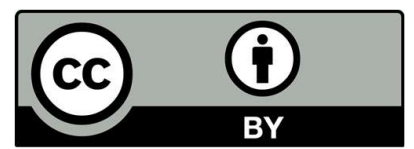

(C) 2020 by the authors; licensee Growing Science, Canada. This is an open access article distributed under the terms and conditions of the Creative Commons Attribution (CCBY) license (http://creativecommons.org/licenses/by/4.0/). 